\title{
Analysis of an Impact of Succession in Mangrove Forest Association Using Remote Sensing and GIS Technology
}

\author{
Nguyen Viet Luong ${ }^{1}$, Ryutaro Tateishi ${ }^{2} \&$ Nguyen Thanh Hoan ${ }^{3}$ \\ ${ }^{1}$ Space Technology Institute, Vietnam Academy of Science and Technology, Vietnam \\ ${ }^{2}$ Chiba University, Chiba-shi, Japan \\ ${ }^{3}$ Institute of Geography, Vietnam Academy of Science and Technology, Vietnam \\ Correspondence: Nguyen Viet Luong, Remote Sensing Application Department, Vien Cong nghe vu tru/Space \\ Technology Institute (STI), Vietnam Academy of Science and Technology (VAST), Vietnam. E-mail: \\ nguyenluongnc@yahoo.com
}

Received: January 14, 2015

Accepted: February 13, 2015

Online Published: February 28, 2015

doi:10.5539/jgg.v7n1p106

URL: http://dx.doi.org/10.5539/jgg.v7n1p106

\begin{abstract}
In this study, we used SPOT HRV satellite data, with $10 \mathrm{~m}$ resolution, from four different years $(1996,2004$, 2007 and 2010) to identify different mangrove forest associations and analyze the change in mangrove associations with time. The classification of mangrove forest association in Can Gio Biosphere Reserves had the overall accuracy between $83.78 \%$ and $88.78 \%$. Forest association change analysis indicated that between 1996 and 2010, the area of 'association I-with the dominant is Rhizophora apiculate' was continuously increased by 18,292.65 ha (average 1,306.62 ha/year): 10,214.79 ha increase between 1996 and 2004, 1,921.41 ha between 2004 and 2007 and 6,156.45 ha between 2007 and 2010. The total area of 'association II-with the dominant are Avicennia alba, Sonneratia alba' decreased by $4,123.86$ ha as much of the forest in this category changed to 'association I' as a result of strict protection. However, there was a small increase in association II ( 820.27 ha) between 2007 and 2010. Over the years, from 1996 to 2010, total area of 'association III-includes species are Phoenix paludosa, Nypa fruiticans, Acathus ebracteatus, Acrostichum aureum' decreased by 11,568.55 ha: 7,273.04 ha (1996-2004), 537.72 ha (2004-2007) and 3,757.79 ha (2007-2010).
\end{abstract}

Keyword: remote sensing, SPOT HRV, GIS, mangrove ecosystem and mangrove forest association change

\section{Introduction}

The existence, development and change of natural processes are inevitable and the mangrove forest is no exception to the phenomena. Mangroves are very sensitive to the environment and it has own change rule. At present $\sim 15$ million ha of mangrove forests exist worldwide and Southeast Asia is well endowed as it supports the world's largest area of mangroves, originally extending over 6.8 million hectares and representing $45.33 \%$ of the world's total [5].

The application of remote sensing data in the study of mangrove vegetation and mangrove cover change has been successfully demonstrated through many previous projects and studies such as: Blasco et al. (1998), Husin et al. (2000), Binh et al. (2008), Liu et al. (2008), Giri et al. (2010), World Atlas of mangrove forest (2010), Chen et al. (2013), Singh et al. (2013), etc. However, most studies have focused on application of remote sensing data on mangrove vegetation and mangrove forest cover change, without regard to detecting change in mangrove forest association and assessing status of the mangrove ecosystems. Although, the mangrove forest associations in the mangrove ecosystems are considered as the basic ecological units for making management decisions to for adopting appropriate silvicultural methods and systems in order to rehabilitate and maintain healthy mangrove ecosystems.

Knowing information of association change, especially on a large area, is very important for prescribing management interventions. Identifying the quantity and direction of changes between different forest associations can be important to layout appropriate silvicultural practices, conservation strategies and reforestation prescription in order to maintain mangrove habitat in a sustainable manner.

This study focuses on identifying the mangrove forest associations in Can Gio mangrove forest in Vietnam, the extent occupied by the identified forest associations in the study area and assess change in forest associations in 
the past.

\section{Study Area}

Geography location: Can Gio district is one of 24 districts of Ho Chi Minh City in Viet Nam, located about 1,300 $\mathrm{km}$ south of $\mathrm{Ha}$ Noi, the captital city of Vietnam. Can Gio mangrove forest lies entirely within the Can Gio district of Ho Chi Minh City. The area lies in geographic co-ordinate between $10^{\circ} 22^{\prime} 14^{\prime \prime} \mathrm{N}-10^{\circ} 40^{\prime} 00^{\prime \prime} \mathrm{N}$ Latitude and $106^{\circ} 46^{\prime} 12^{\prime \prime}-107^{\circ} 00^{\prime} 59^{\prime \prime}$ E Longitude. On January $21^{\text {st }}, 2000$, MAB/UNESCO Committee recognized Can Gio mangrove forest as International Biosphere Reserve and the first biosphere reserve in Vietnam [22].

\section{Data and Methodology}

\subsection{Satellite Data}

Système Probatoire de l'Observation de la Terre (SPOT) satellite data with $10 \mathrm{~m}$ spatial resolution- SPOT-4 (1996), SPOT-5 (2004, 2007, and 2010), was used in this study: has four-time data used were taken from the same season as the data from different season are prone to errors due to possible difference in reflectance values for the same vegetation type as a result of phenology. Details of the satellite data used in the present study are given in the Table 1, Figure 1.

Table 1. Details of satellite data used in the study

\begin{tabular}{ccccccc}
\hline No. & Satellite & Sensor & Date of pass & Total bands & Spectral bands used & Spatial resolution (m) \\
\hline 1 & Spot 4 & HRV & March 1996 & 3 & $1,2,3$ & 10 \\
2 & Spot 5 & HRV & April 2004 & 3 & $1,2,3$ & 10 \\
3 & Spot 5 & HRV & March 2007 & 3 & $1,2,3$ & 10 \\
4 & Spot 5 & HRV & March 2010 & 3 & $1,2,3$ & 10 \\
\hline
\end{tabular}

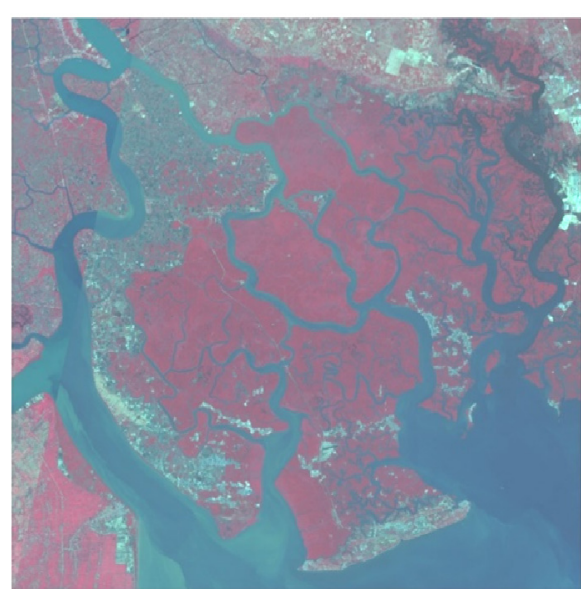

(a)

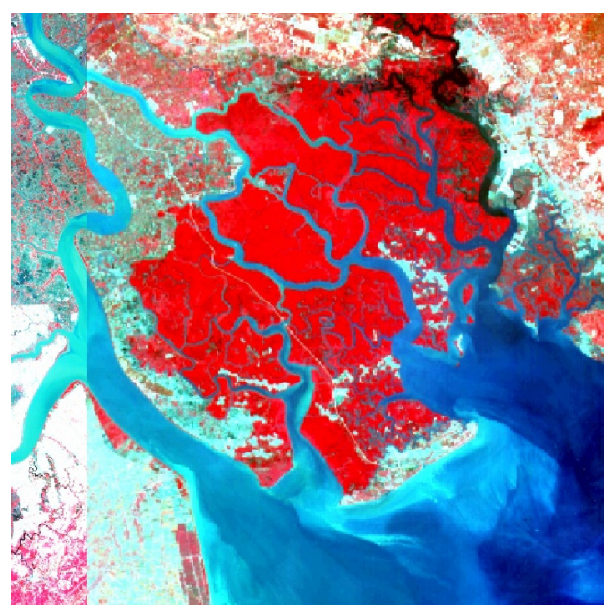

(c)

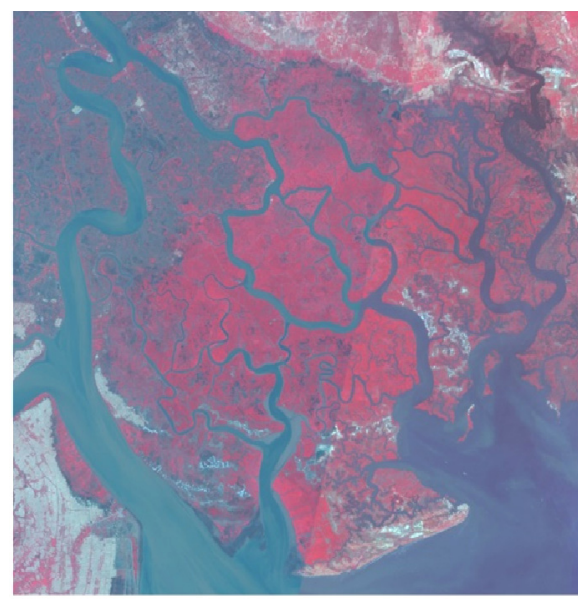

(b)

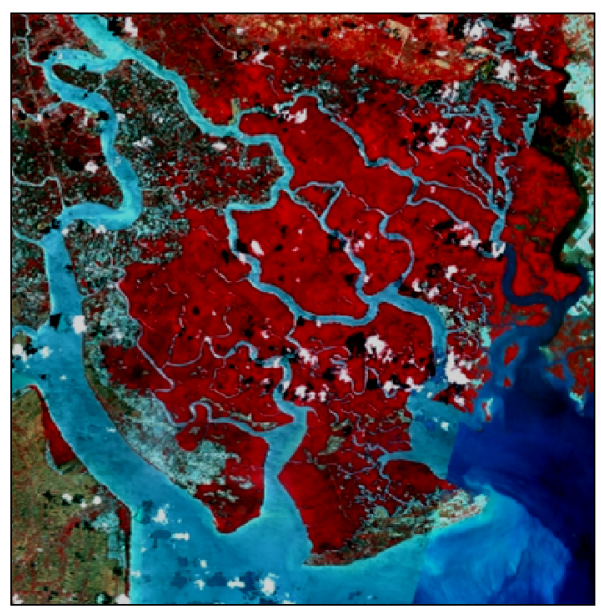

(d)

Figure 1. False colour composite of SPOT HRV in 1996 (a), 2004 (b), 2007 (c) and 2010 (d) 


\subsection{Satellite Image Processing}

Geometric correction; Image to map rectification; Image to Image registration; Change detection analysis. Post classification comparison method (based on supervised classification) was adopted for change analysis.

\subsection{Field Work}

Data collected from the sample plots and check the accuracy. In this study, a typical sample plot of $500 \mathrm{~m}^{2}(25 \mathrm{~m}$ x $20 \mathrm{~m}$ ). Methods of measurement at each sample plot: At each sample plot various information on the individual woody trees such as name of tree species (local and scientific names), the diameter at breast height (DBH), the height $(\mathrm{H})$, the diameter of canopy of each trees were recorded and GPS camera was used.

\subsection{Inheriting the Previous Studies}

Similar to the temporal and spatial distribution of individual mangrove tree species, the distribution of the natural floral associations also follows rules that depend closely on the tidal regime and the stability of the substrate. The research related to association distribution in this area has Cuong (1964) and Tuan (2002) about relationship between tidal regime physical trees distribution is given the Table 2. Another research as such as: Trung (1978, 1998), Tri (1999) and Hong $(1984,1997)$ also the same opinion.

Table 2. The relationship between tidal regime-physical-trees distribution

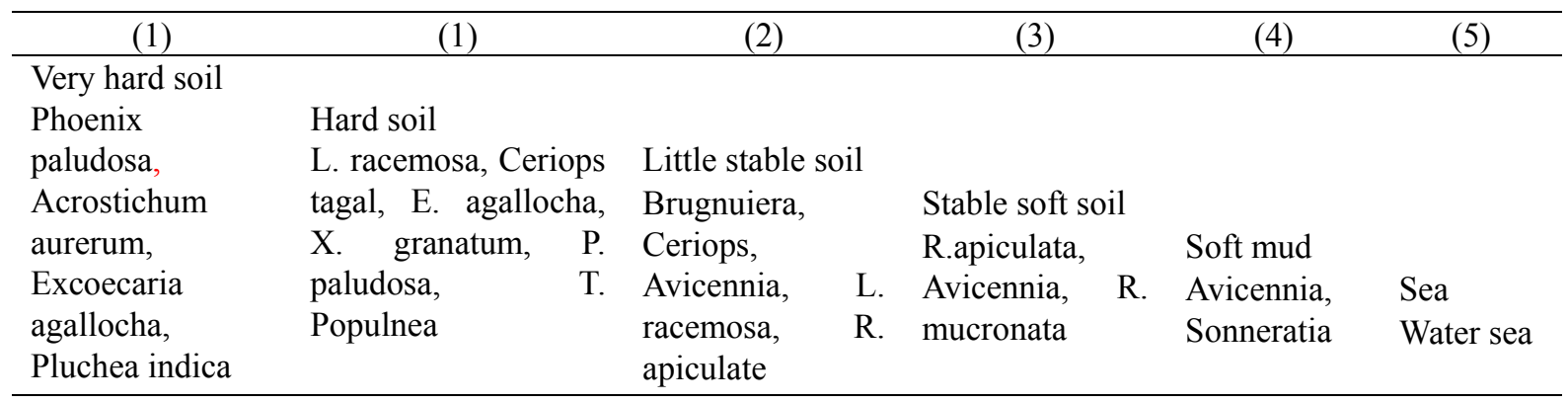

Note: (1). Prone to very occasional flooding- Tidal level $>4 \mathrm{~m}$; (2). Floods at occasionally high spring tidesTidal level 3.5m-4m; (3). Floods at occasionally medium spring tide- Tidal level $2.5 \mathrm{~m}-3.5 \mathrm{~m}$; (4). Floods at occasionally low spring tides-Tidal level $2 \mathrm{~m}-2.5 \mathrm{~m}$; (5). Sea- Tidal level $<1.5 \mathrm{~m}$.

\section{Results}

\subsection{The Survey Results from the Sample Plots}

The results of survey from sample plots from the field and is given details in Table 3 below:

Association I: This category has Rhizophora apiculate as a dominant species and are found on areas with stable land-This association covers large areas, becoming an important forest type in here.

Association II: This association often occupies the interface between land and sea area and often include pioneering species where Avicennia alba, Sonneratia alba are dominant. They are distributed on newly formed mudflats or/and newly formed alluvial flat along estuaries, watery, estuarine and coastal area and can tolerate high salinity.

Association III: This category includes small tree/shrub and grassy vegetation found on higher mudflats, higher land and small tree species.

Another area: Bare soil, water (non-forest cover). 
Table 3. Interpretation key of satellite imagery and structural characteristics of the mangrove forest

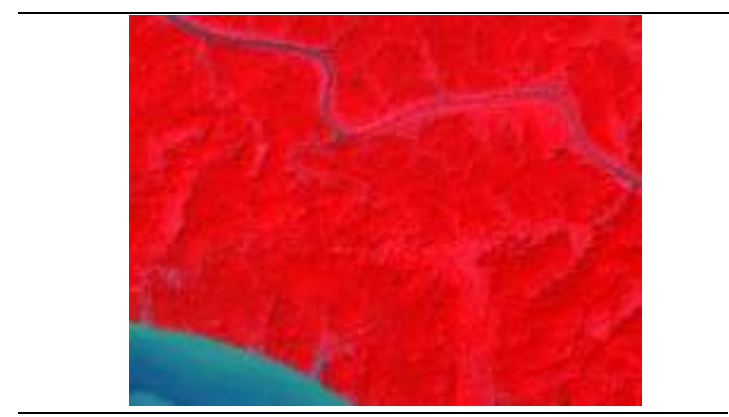

Dark red and fine structure

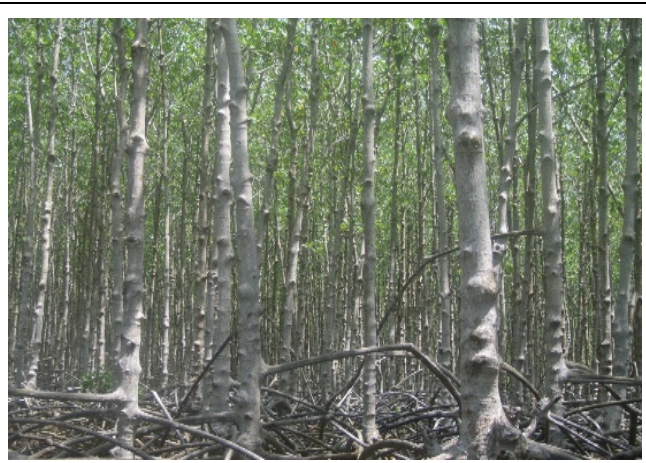

Canopy of forest $>75 \%$, height tree $>10 \mathrm{~m}$ and diameter of woody tree $>10 \mathrm{~cm}$ and density of woody tree is 1,197 tree/ha. The species composition (ratio 1/10) is 7.16 Rhizophora apiculate +1.14 Avicennia alba +0.93 Exceocacia agallocha +0.28 Sonneratia alba +0.24 Ceriops tagal +0.22 Lumnitzera racemonsa +0.02 Lumnitzera littorea +0.01 Aegyceras corniculatum.

\begin{tabular}{l}
\hline Association I \\
\hline
\end{tabular}

\section{Association II}

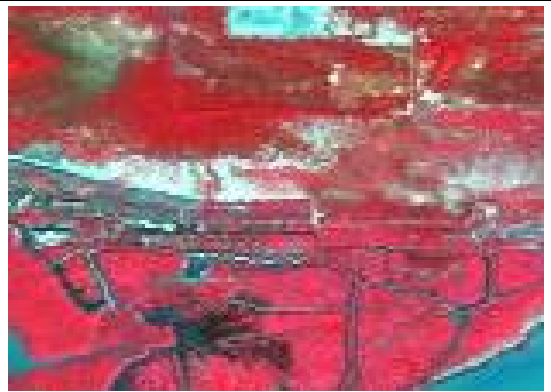

Light red, fine to very fine structure. Shape is not clear

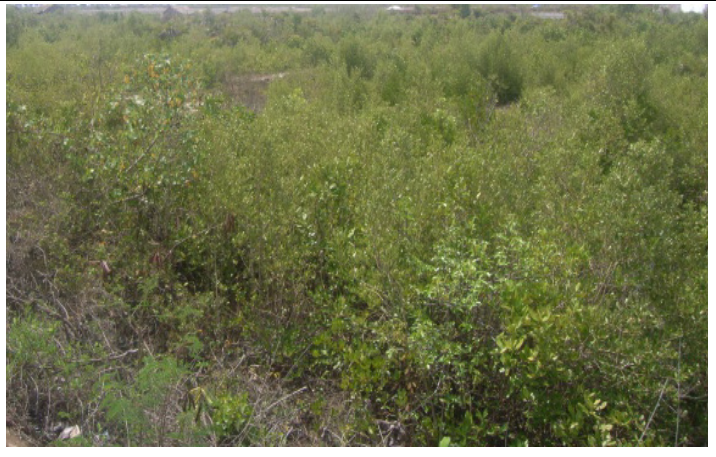

Phoenix paludosa, Nypa fruiticans, Acathus ebracteatus, Acrostichum aureum... and some true mangrove species as Rhizophora apiculate, Avicennia alba, Exceocacia agallocha, Sonneratia alba...However, the height tree $<6 \mathrm{~m}$, diameter of woody species $<5 \mathrm{~cm}$ and density of tree is 103,692 tree/ha. 


\subsection{Mapping of Mangrove Forest Associations}

\subsubsection{Mangrove Forest Association Map of 1996}

Mangrove forest association map based on supervised classification of SPOT 1996 is show in Figure 2 and analysis of mangrove forest association area is given in Table 4. The association I area is 11,058.40 ha (14.94\%), association II area is $13,156.40$ ha $(17.77 \%)$, association III area is $14,649.10$ ha $(19.78 \%)$ and another land is $35,192.60$ ha $(47.52 \%)$. The overall accuracy is $84.89 \%$ and average accuracy of $82.95 \%$. Kappa statistics (K) is 0.7994 .

Table 4. Mangrove forest association of 1996

\begin{tabular}{lrr}
\hline \multicolumn{1}{c}{ Class } & Area (ha) & Percent (\%) \\
\hline Association I & $11,058.40$ & 14.93 \\
Association II & $13,156.40$ & 17.77 \\
Association III & $14,649.10$ & 19.78 \\
Another land & $35,192.60$ & 47.52 \\
$\quad$ Total & $74,056.50$ & 100.00 \\
\hline
\end{tabular}

\subsubsection{Mangrove Forest Association Map of 2004}

The mangrove forest association map based on supervised classification for 2004 is given in Figure 3. The area statistics for mangrove forest association is given in Table 5. The association I area is 21,273.19 ha (28.73\%), association II area is $8,628.05$ ha $(11.65 \%)$, association III area is $7,376.06$ ha $(9.96 \%)$ and another land area is $36,779.20$ ha (49.66\%). The overall accuracy is $84.99 \%$ and average accuracy of $82.00 \%$ and Kappa statistics is 0.8905 .

Table 5. Mangrove forest association of 2004

\begin{tabular}{lcr}
\hline \multicolumn{1}{c}{ Class } & Area (ha) & Percent (\%) \\
\hline Association I & $21,273.19$ & 28.73 \\
Association II & $8,628.05$ & 11.65 \\
Association III & $7,376.06$ & 9.96 \\
Another land & $36,779.20$ & 49.66 \\
Total & $74,056.50$ & 100 \\
\hline
\end{tabular}

\subsubsection{Mangrove Forest Association Map of 2007}

The mangrove forest association map based on supervised classification for 2007 is shown in Figure 4. The area statistics for mangrove forest association of 2007 is given in Table 6. The association I area is 23,194.60 ha ( $31.32 \%)$, the association II area is $8,212.27$ ha $(11.09 \%)$, the association II area is $6,838.34$ ha $(9.23 \%)$ and another land area is $35,811.29$ ha $(48.36 \%)$. The overall accuracy assessment of mapping is $83.78 \%$ and average accuracy of $71.00 \%$. Kappa statistics $(\mathrm{K})$ is 0.7609 .

Table 6. Mangrove forest association of 2007

\begin{tabular}{lcc}
\hline Class & Area (ha) & Percent (\%) \\
\hline Association I & $23,194.60$ & 31.32 \\
Association II & $8,212.27$ & 11.09 \\
Association III & $6,838.34$ & 9.23 \\
Another land & $35,811.29$ & 48.36 \\
$\quad$ Total & $74,056.50$ & 100.00 \\
\hline
\end{tabular}

\subsubsection{Mangrove Forest Association Map of 2010}

The mangrove forest association map based on supervised classification for 2010 is shown in Figure 5 and the area statistics for mangrove forest association of 2010 is given in Table 7. The association I area is 29,351.05 ha (39.63\%), association II area is $9,032.50$ ha $(12.20 \%)$, association III area is 3,080.55 ha (4.16\%) and another land area is $32,592.39$ ha $(44.01 \%)$. The overall classification accuracy of mapping using confusion matrix is 
$88.78 \%$ and average accuracy of $83.99 \%$. Kappa statistics $(\mathrm{K})$ is 0.8221 .

Table 7. Mangrove forest association of 2010

\begin{tabular}{lrr}
\hline \multicolumn{1}{c}{ Class } & \multicolumn{1}{c}{ Area (ha) } & Percent (\%) \\
\hline Association I & $29,351.05$ & 39.63 \\
Association II & $9,032.50$ & 12.20 \\
Association III & $3,080.55$ & 4.16 \\
Another land & $32,592.39$ & 44.01 \\
Total & $74,056.50$ & 100.00 \\
\hline
\end{tabular}

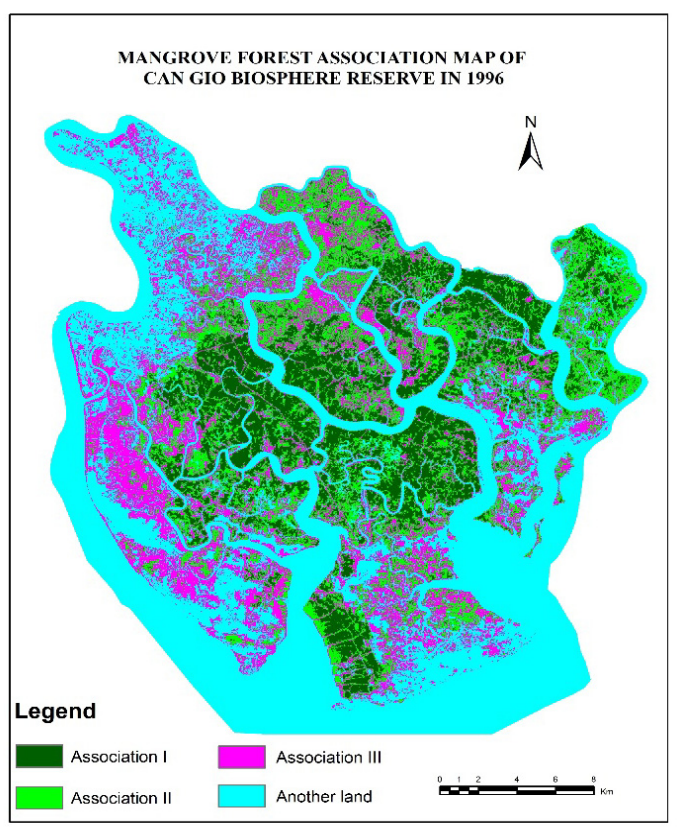

Figure 2. Mangrove forest association map in 1996

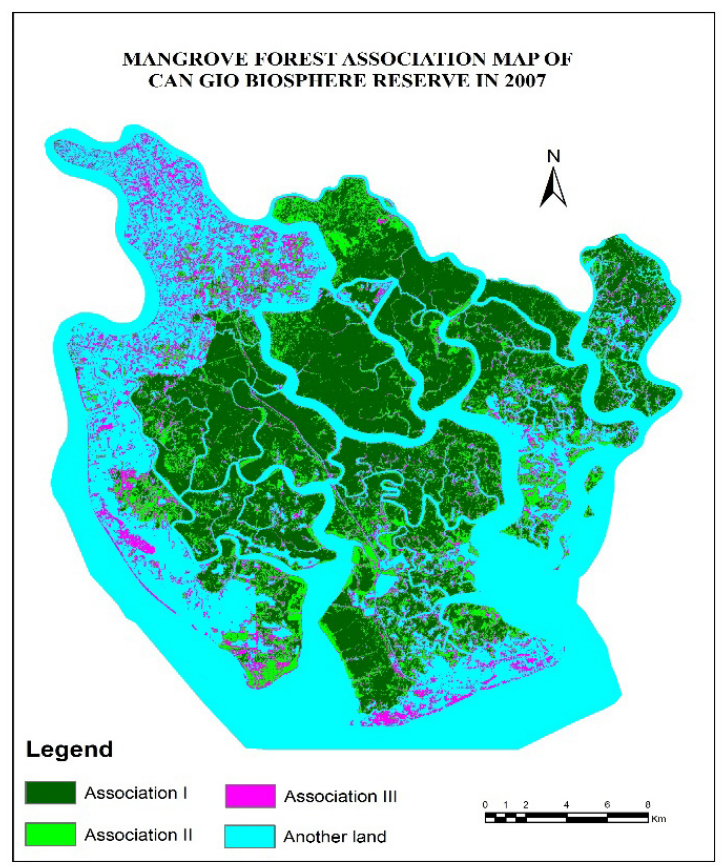

Figure 4. Mangrove forest association map in 2007

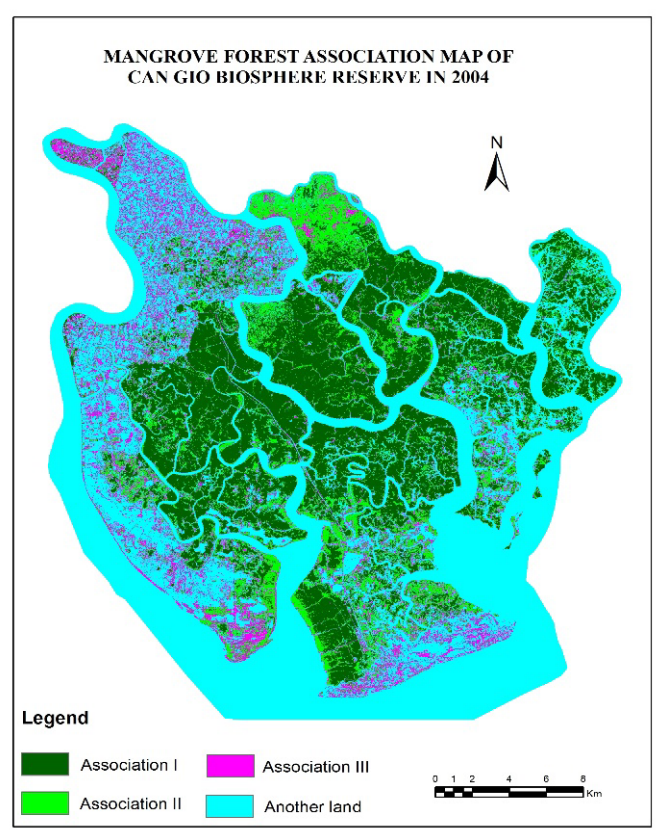

Figure 3. Mangrove forest association map in 2004

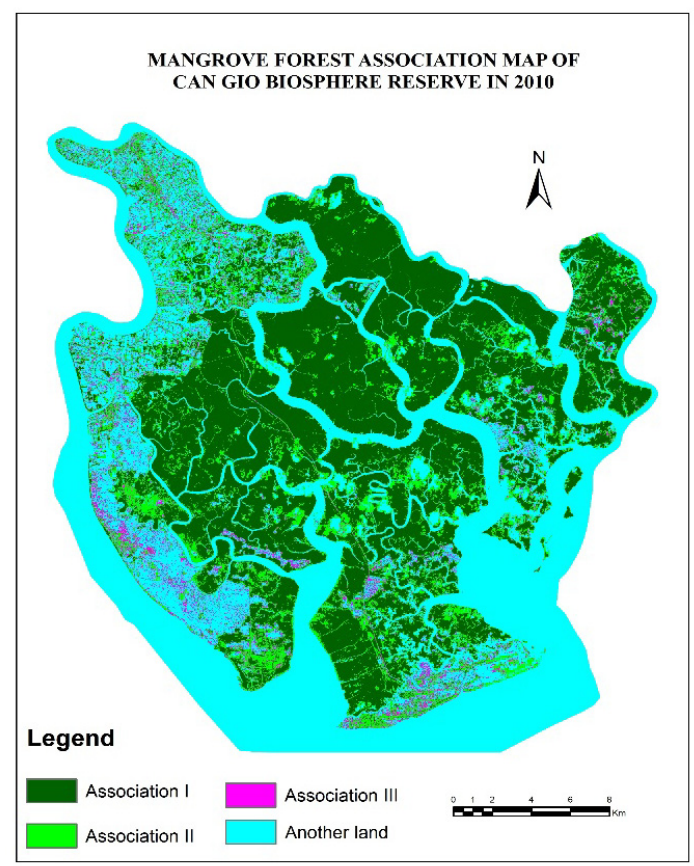

Figure 5. Mangrove forest association map in 2010 


\subsection{Change Maps of Mangrove Forest Associations}

The post classification comparison method was followed to find the change of mangrove forest associations from 1996 to 2004, 2004 to 2007 and 2007 to 2010.

\subsubsection{Comparative Change of Mangrove Forest Association from 1996 to 2004}

The results of geospatial change maps from 1996 to 2004 based on post classification comparison method and area analysis shown in Figure 6, Table 8, 9. The analysis indicate that the association I area increased by 10,214.79 ha. While the association II area decrease by 4,528.35 ha, association III area declined by 7,273.04 ha. Nevertheless, another land area increased by $1,586.60$ ha.

Table 8. Area change matrix from 1996 to 2004 (units: ha)

\begin{tabular}{|c|c|c|c|c|c|c|}
\hline 1996 & 2004 & Association I & Association II & Association III & Another land & Total \\
\hline Association I & & $10,248.50$ & 417.98 & 90.28 & 301.64 & $11,058.40$ \\
\hline Asso & & & 48 & 893.36 & 18 & $13,156.40$ \\
\hline Assoc & & 00 & 70 & $2,949.24$ & 4,72 & $14,649.10$ \\
\hline Another land & & 657.31 & $1,498.89$ & $3,443.18$ & $29,593.22$ & $35,192.60$ \\
\hline Total & & $21,273.19$ & $8,628.05$ & $7,376.06$ & $36,779.20$ & $74,056.50$ \\
\hline
\end{tabular}

Table 9. Mangrove forest association change during from 1996 to 2004 (units: ha)

\begin{tabular}{lrrr}
\hline \multicolumn{1}{c}{ Class } & Area (1996) & Area (2004) & Area (Change) \\
\hline Association I & $11,058.40$ & $21,273.19$ & $10,214.79$ \\
Association II & $13,156.40$ & $8,628.05$ & $-4,528.35$ \\
Association III & $14,649.10$ & $7,376.06$ & $-7,273.04$ \\
Another land & $35,192.60$ & $36,779.20$ & $1,586.60$ \\
$\quad$ Total & $74,056.50$ & $74,056.50$ & 0.00 \\
\hline
\end{tabular}
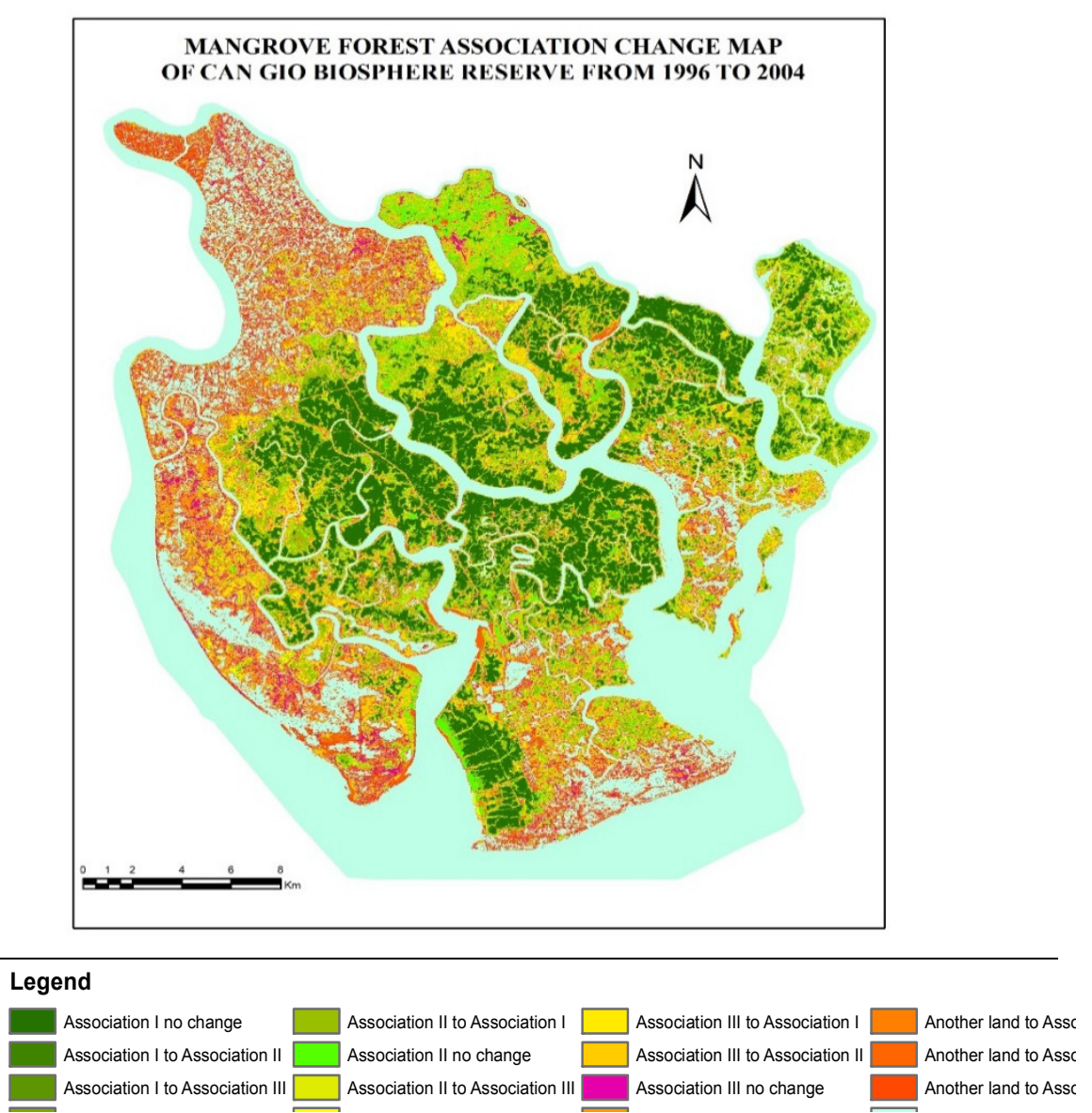

Figure 6. Mangrove forest association change map of Can Gio Biosphere reserve from 1996 to 2004 
4.3.2 Comparative Change of Mangrove Forest Association from 2004-2007

The results of geospatial change maps from 2004 to 2007 based on post classification comparison method area shown in Figure 7, Table 10, 11. The analysis indicate that the association I area increased by 1,921.41 ha. While the association II area decrease by 415.78 ha, association III area declined by 537.72 ha and another land area decrease by 967.91 ha.

Table 10. Mangrove forest association change during from 2004 to 2007 (units: ha)

\begin{tabular}{lrrrrr}
\hline \multicolumn{1}{c}{2004} & Association I & Association II & Association III & Another land & \multicolumn{1}{c}{ Total } \\
\hline Association I & $18,025.80$ & $2,391.85$ & 554.46 & 301.08 & $21,273.19$ \\
Association II & $3,247.26$ & $3,313.32$ & $1,262.15$ & 805.32 & $8,628.05$ \\
Association III & 527.45 & $1,303.56$ & $2,394.22$ & $3,150.83$ & $7,376.06$ \\
Another land & $1,394.09$ & $1,203.54$ & $2,627.51$ & $31,554.06$ & $36,779.20$ \\
Total & $23,194.60$ & $8,212.27$ & $6,838.34$ & $35,811.29$ & $74,056.50$ \\
\hline
\end{tabular}

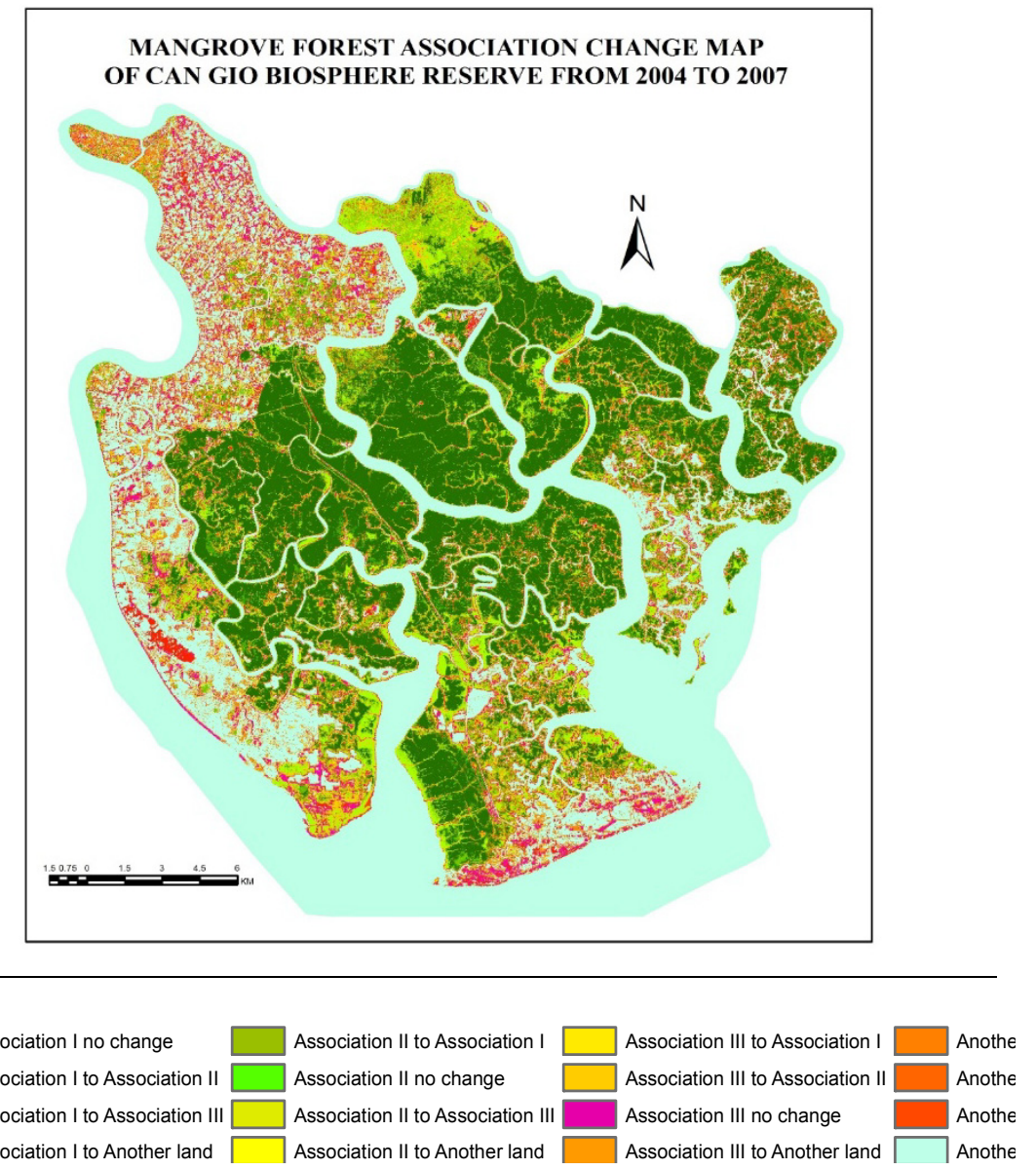

Figure 7. Mangrove forest association change map of Can Gio Biosphere reserve from 2004 to 2007

Table 11. Mangrove forest association change during from 2004-2007 (units: ha)

\begin{tabular}{lccr}
\hline \multicolumn{1}{c}{ Class } & Area (2004) & Area (2007) & Area (Change) \\
\hline Association I & $21,273.19$ & $23,194.60$ & $1,921.41$ \\
Association II & $8,628.05$ & $8,212.27$ & -415.78 \\
Association III & $7,376.06$ & $6,838.34$ & -537.72 \\
Another land & $36,779.20$ & $35,811.29$ & -967.91 \\
$\quad$ Total & $74,056.50$ & $74,056.50$ & 0.00 \\
\hline
\end{tabular}


4.3.4 Comparative Change of Mangrove Forest Association from 2007-2010

The results of geospatial change maps from 2007 to 2010 based on post classification comparison method area shown in Figure 8, Table 12, 13. The analysis indicate that the association I area increased by $6,156.46$ ha and association II area increased by 820.23 ha. While the association III area decrease by $3,757.79$ ha and another land area decrease by $3,218.90$ ha.

Table 12. Mangrove forest association change during from 2007 to 2010 (units: ha)

\begin{tabular}{|c|c|c|c|c|c|c|}
\hline 2007 & 2010 & Association I & Association II & Association III & Another land & Total \\
\hline Association I & & $20,573.00$ & $1,961.38$ & 50.48 & 609.74 & $23,194.60$ \\
\hline Asso & & & 75 & 105.96 & 562.96 & $8,212.27$ \\
\hline Assoc & & & & 721.76 & $1,579.85$ & $6,838.34$ \\
\hline Another land & & $1,014.36$ & $2,754.74$ & $2,202.35$ & $29,839.84$ & $35,811.29$ \\
\hline Total & & $29,351.06$ & $9,032.50$ & $3,080.55$ & $32,592.39$ & $74,056.50$ \\
\hline
\end{tabular}

Table 13. Mangrove forest association change during from 2007-2010 (units: ha)

\begin{tabular}{lrrr}
\hline \multicolumn{1}{c}{ Class } & Area (2007) & Area (2010) & Area (Change) \\
Association I & $23,194.60$ & $29,351.06$ & $6,156.46$ \\
Association II & $8,212.27$ & $9,032.50$ & 820.23 \\
Association III & $6,838.34$ & $3,080.55$ & $-3,757.79$ \\
Another land & $35,811.29$ & $32,592.39$ & $-3,218.90$ \\
$\quad$ Total & $74,056.50$ & $74,056.50$ & 0.00 \\
\hline
\end{tabular}
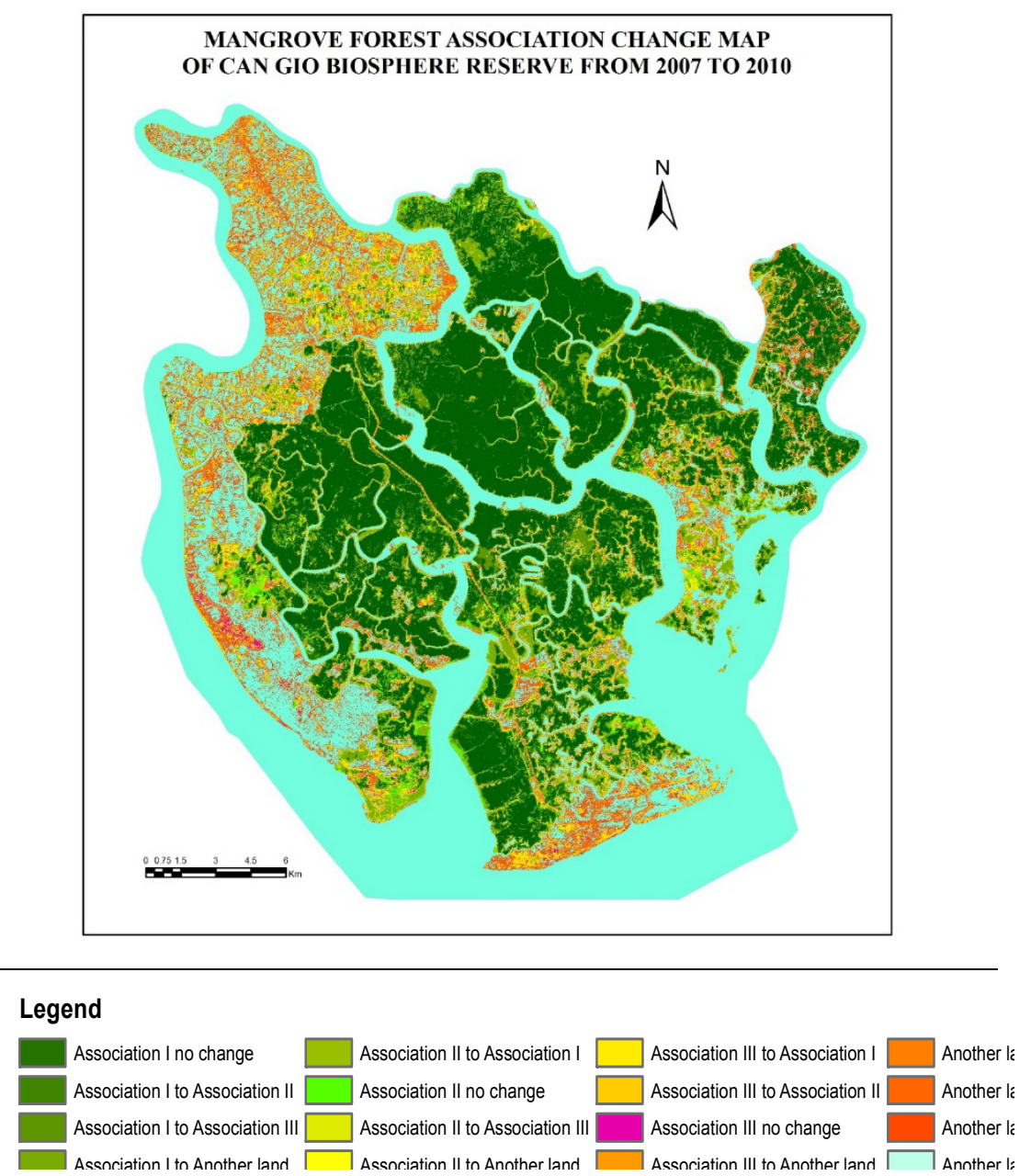

Figure 8. Mangrove forest association change map of Can Gio Biosphere reserve from 2007 to 2010 


\section{Discussion}

In this study used optical satellite imagery (SPOT-4, SPOT-5). For the optical sensor: spectral reflectance data collected in visible and infrared region. Thus, information from optical satellite imagery observed mostly from the surface of the canopy. Therefore, the information extracted from satellite images have been limited to the recorded information, describes information inside of the structure of association such as diameter, height and density of trees. In the future work, this research should be combined with other data such as microware data, lidar data in monitoring of mangrove forest association. Even so, of course, the results of this study are useful for planning, policy direction in the management and sustainable development of the mangroves ecosystem.

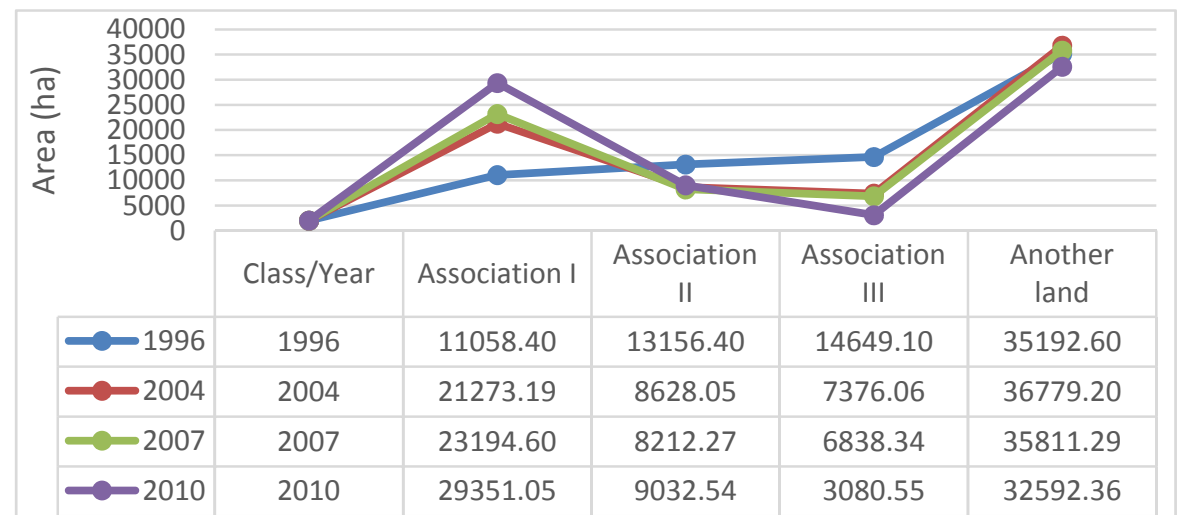

Figure 9. Mangrove forest association change 1996, 2004, 2007 and 2010

\section{Conclusions}

From images of SPOT-4, SPOT-5 with $10 \mathrm{~m}$ resolution, application of the standard procedure of supervised classification approach was followed and maximum likelihood algorithm classification had demonstrate that efficient and effective use for mapping off mangrove forest association with overall accuracy between $83.78 \%$ and $88.78 \%$. Forest association change analysis indicated that between 1996 and 2010, the area of 'association I' was continuously increased by $18,292.65$ ha (average 1,306.62 ha/year), including: 10,214.79 ha increase between 1996 and 2004, 1,921.41 ha (2004-2007) and 6,156.45 ha between 2007 and 2010. The total area of 'association II' decreased by $4,123.86$ ha as much of the forest in this category changed to 'association I' as a result of strict protection. However, there was a small increase in association II ( 820.27 ha) between 2007 and 2010. Over the years, from 1996 to 2010, total area of 'association III' decreased by 11,568.55 ha, including: 7,273.04 ha (1996-2004), 537.72 ha (2004-2007) and 3,757.79 ha (2007-2010). Similarly 'another land area' also decreased by 2,600.24 ha between 1996 and 2010. Finally our results show that total area of all available mangrove forest associations increased by $2,600.24$ ha in the period from 1996 to 2010. This increase is attributed to the corresponding decrease of 'another land area' category in our study area. Full scene of mangroves forest association change through the period of study area has brief description at the Figure 9 Based on our findings we recommend following strategies to monitor the mangrove habitat:

- Continuous monitoring of the mangrove forest association using data from satellite images with high resolution and after every years are preferable.

- Remote sensing optical data in combination with radar data may be more useful in monitoring changes of mangrove forest association.

- The association I forest in this study area should be thinned to allow more light to penetrate through the canopy and facilitate increase in diameter.

\section{Acknowledgments}

The authors express their gratitude to the President of Vietnam Academy of Scienceand Technology (VAST), Director of Rufford Small Grant and Japan Society for the Promotion of Science (JSPS) have encouraged, supported and provided fundingfor this study.

\section{References}

Binh, T. H. B., Luong, N. V., Hoa, P. V., \& Thoa, P. T. K. (2008). Using Multi-Temporal Remote Sensing Data to Manage the Mangrove for Coastal Environmental Protection. Remote Sensing and Spatial Information Sciences.Vol. XXXVII. Part B8.Beijing, China, pp.709-711. 
Blasco, F., Gauquelin, T., \& Rasolofoharinoro, M., et al. (1998). Recent advances in mangrove studies using remote sensing data. Mar. Freshwater Res., 49, 287-96. http://dx.doi.org/10.1071/MF97153

Chen, C. F., Son, N. T., \& Chang, B. N. et al. (2013). Multi-Decadal Mangrove Forest Change Detection and Prediction in Honduras, Central America, with Landsat Imagery and a Markov Chain Model.

Cuong, V. V. (1964). Flore et vegetation de la mangrove de la région de Saigon - Cap Saint Jacques, sud Vietnam, Thèse Docteur 3e Cycle, Univ. Paris. 3re cycle, 188 pp.

Giri, C., Ochieng. E., \& Tieszen, L. L. et al. (2011). Status and distribution of mangrove forest of the world using earth observation satellite data. Global Ecology and Biogeography, (Global Ecol. Biogeogr.), 20, 154-159, pp.156. http://dx.doi.org/10.1111/j.1466-8238.2010.00584.x

Hoc, T. Q. (2001). Dictionary of Biodiversity and related sustainable development terms. Science and Technics Publishing House, Hanoi, 509, 31.

Hong, P. N. (1997). Role of mangrove forest in Vietnam. Science and Technics Publishing House, Hanoi.

Hong, P. N. (1999). Vietnamese mangrove forest. Agriculture Publishing House, Hanoi, 205, 26-57.

Liu, K., Li, X., Shi, X. S., \& Wang, S. (2008). Monitoring mangrove forest changes using remote sensing and GIS data with decision learning. WETLANDS, 28(2), 336-346. http://dx.doi.org/10.1672/06-91.1

Luong, N. V. (2011). The vegetation in Can Gio mangrove forest after 10 years of MAB/UNESCO recognized as an International Biosphere Reserve. The 4-th National Scientific Conference on Ecology and Biological Resources, 8, 1687-1693.

Luong, N. V. (2012). Mangrove forest structure of coverage change analysis using Remote Sensing and Geographical Information System technology: A case study of Can Gio district, Ho Chi Minh city, Vietnam. Rufford Small Grant-England project, 45.

Luong, N. V. (2012). Overview of mangroves Vietnam-Technical report-JICA project-MARD, 96, 5.

MARD. (2008). Scheme: Rehabilitation and development of coastal mangrove in Vietnam period 2008-2015.

Maurand, P. L. Indochine forestière. (1943). Inst. Rech. Agro. Indochine. 2-3, 185-194.

Nam, V. N. et al. (2014). Study in Can Gio Mangrove Biosphere Reserve-An Overview of Can Gio District and Mangrove Biosphere Reserve. International Societ for Mangrove Ecosystems-ISME Mangrove Ecosystems Technical Reports No.101, 17.

Ross, P. (1975). The Mangrove of southern Vietnam: The impact of military use of herbicides. In Walsh, G. E., S. C. S., \& Teas, H. J. (Eds.), Proc. Int. Symp. Manage. Mangr, 8 - 11 October 1974, East-West Center, Honolulu. 2. pp. 3-22, 695-700.

Sarnam, S., Luong, N. V., \& Binh, T. T. H. (2013). Mangrove Forest Reclamation Monitoring Using Geospatial Tools in Can Gio Mangrove Biosphere Reserve, Vietnam. International Journal of Ecology and Environmental Sciences, 39(3), 147-158, ISSN: 0377-015X (Print); 2320-5199 (Online).

Sremongkontip. S., Hussin, Y. A., \& Groenindijk, L. (2000). Detecting changes in the mangrove forests of southern Thailand using remotely sensed data and GIS. International Archives of Photogrammetry and Remote Sensing. Vol. XXXIII, Part B7. Amsterdam 2000.

Tri, N. H. (1999). The Bioecology of mangrove forest in Vietnam. Agriculture Publishing House. Hanoi, 369, 40.

Trung, T. V. (1978). The vegetation cover in Vietnam. Science and Technics Publishing House. Hanoi, 276, 44.

Trung, T. V. (1998). The tropical forest ecosystem in Vietnam. Science and Technics Publishing House, Hanoi, 298, 51.

Tuan, L. D., \& Oanh, T. K. D., \& Thanh, C. V. et al. (2002). Can Gio Mangrove Biosphere Reserve. Agriculture Publishing House. Ho Chi Minh City.

World Atlas of Mangrove. (2010). First published by Earthscan in the UK and USA, 337, 1.

\section{Copyrights}

Copyright for this article is retained by the author(s), with first publication rights granted to the journal.

This is an open-access article distributed under the terms and conditions of the Creative Commons Attribution license (http://creativecommons.org/licenses/by/3.0/). 